\title{
DONATIO MORTIS CAUSA OF ONE'S OWN CHECK.
}

I. Development of Principle. The purpose of this article is to maintain that a donatio mortis causa may be well executed, in equity, upon the giving of a check by the donor, even though the check is not paid or presented before the donor's death.

The recent decision by the United States Supreme Court in Fourth Street Bank v. Yardley, I65 U.S. 634, strengthens the doubt of those who have questioned certain English decisions by courts of the first instance denying validity to such gifts.

Since there are a few cases, a very few, in which the gift under such circumstances has been held to have failed for want of execution, it is just as well to say at the outset that there is no desire to cut a figure by assailing decisions of courts of great respectability. The work of reverting to the main column of decisions, from which it is apprehended some temporary wandering has occurred, is the present and more gracious endeavor.

Let it be remembered that it was recognized at a very early day that "there are many articles which might be made the subjects of a donation mortis causa, in which a manual delivery might be inconvenient or impracticable." 1 Thus delivery of the key to bulky casks wherein wines, etc., are, was allowed as delivery of possession because, said Lord Hardwicke, " it is the way of coming at the possession or to make use of the thing." 2

The law having recognized the principle that delivery of the means of coming at possession is sufficient evidence of a gift, plenty of occasions arose to give the principle activity.

In 1744, Lord Chancellor Hardwicke had before him Snelgrove v. Bailey, 3 Atk. 214. In that case the bond of a third person in favor of donor was delivered by the donor to the donee as a gift mortis causa. Lord Hardwicke held that there

I Coleman v. Parker, II4 Mass. 30.

${ }^{2}$ Ward v. Turner, 2 Ves. Sr. 43r, 443.

246 
was a good gift. He said: "You cannot sue at law without the bond; for though you may give evidence of a deed at law that is lost, yet you cannot of a bond, because you must make a profert of it." Now this language of the chancellor was very narrow and needlessly technical ; but nevertheless it recognized anew the doctrine applied in the case of keys to articles inconvenient of carriage, viz.: that delivery of the means of getting at the possession will effect a good donatio mortis causa which equity will enforce. ${ }^{1}$

The recognition of the effect of Snelgrove v. Bailey was for a long time slow, and much contested. There was much incumbrance, too, by other difficulties. In cases of mortgages, there was question whether the statute of frauds operated to prohibit parol gifts of what might be thought to convey interests

${ }^{1}$ As the text intimates, Snelgrove $v$. Bailey has the appearance of resting on narrow grounds: Delivery of the bond is actual delivery of some property; the law puts it in the donee's power, by destruction of the bond, to destroy donor's action (at common law) by thus preventing profert. Moreover, the English law was that bonds have locality, and are bond notabilia, so that the administration must be taken out in the diocese where it is found. These things being so, delivery of the bond was quite a clear manifestation of a parting with dominion, and was sufficient to satisfy a chancellor that he should enforce the intent of the donor. If we regard these as being the chancellor's reasons, and regard the decision as lacking support on any general principle applicable in cases of instruments other than bonds, then we are compelled to regard the decision of that great judge as being an isolated and arbitrary one. For there are other instruments delivery of which attest quite as strongly the purpose of yielding dominion; as where a mortgagor, or a third person's note is handed over to a donee. The reasons of Lord Hardwicke appear, however, to be put in the way of illustration of a general principle. There are two indications of this, as Irord Eldon pointed out in Duffield v." Elwes, I Bli. N. R. In the opinion, Lord Hardwicke refers to delivery of government tally sticks, etc., as analogous cases. And in Ward $v$. Turner, 2 Ves. Sr. 43I, decided by him eight years afterwards, after remarking that he could go no further than he went in Snelgrove $v$. Bailey, he went on to say that since the stock receipts of his day were " waste papers," "no evidence of the thing," delivery of them was of no avail to sustain the gift. This shows quite clearly that his theory in Snelgrove $v$. Bailey was that he could extend aid where the instrument delivered represented the debt in such a manner that if the donor parted with it the donor delivered the means of getting at possession. Snelgrove $v$. Bailey, then, must be taken to assert a general principle, one not confined to the cases of bonds, as is well explained by Lord Fidon in the complementary case of Duffield $v$. Elwes, I Bli. N. R. 497. 
in land. In the case of certificates of stock, trouble was encountered by reason of the requirement, that transfer must be approved by the corporation and registered in the corporation books. This difficulty is possibly not entirely cleared away, yet, although one can scarcely see how any court can hesitate here unless it is ready to overrule Lord Hardwicke and Lord Eldon. We think these difficulties disappear, so soon as it is appreciated that the courts recognize the theory of equitable assignment as between donor's estate and the donee, upon a delivery by the donor of the means of getting possession.

In Duffield v. Elzves, I Bli. N. R. 497, there was delivery of a bond for $£ 2927$, and of a mortgage securing the same money; also there was delivery of a mortgage for $£ 30,000$, judgment notes, etc., the whole aggregating upwards of one hundred and fifty thousand dollars. There was also a written statement delivered declaring the gift of the bond and of the two mortgages. A judgment on the bond was also conveyed by the said statement.

The House of Lords decided that delivery of the mortgage attested the gift of the debt it secured, and that the debt being given, carried with it the mortgage. Lord Eldon commented at large on the objection that conveyance of land should be in accordance with the statute of frauds, and held that the objection could not stand; that the conveyance was of the mortgage debt and not of the land.

The second difficulty was as to perfecting gifts mortis cansa void at law. This, as has been seen, was done first in Snelgrove v. Bailey, where the chancellor perfected the gift of a bond, although the gift was void at law. And although Lord Hardwicke afterwards said, in Ward v. Turner, that he could go no further than he went in Snelgrove v. Bailey, we have seen that he meant that he could not extend aid where the instrument did not represent the debt in a manner that made it a means of getting possession of the money. In Duffield $\mathrm{v}$. Elwes, Lord Eldon said that the principle that equity will perfect donations mortis causa when the donor has parted with

${ }^{1}$ See Richards $v$. Sims, 2 Atk. 319; Hassel $v$. Tyorte, I Amb. I3r8; Hirst $v$. Beach, 5 Madd. 35I ; Duffield $v$. Elwes, I Bli. N. R. 497. 
the means of getting at the property ought not to be narrowed by mere technicalities; that the chancellor ought not to lay stress, therefore, on Lord Hardwicke's remarks respecting bonds as distinguished from most other instruments representing property, especially as one of the peculiarities relied upon by that judge, namely, the need of profert in suit on the bond, was so very technical that now it is no longer necessary, when the bond is lost. Accordingly, the House of Lords preferred a more general rule. It was determined, then, that because the mortgage represented the debt, " formed part of the title," the debt itself passed, not, indeed, at law, nor yet in equity, as against the donor mortis causa, but passed sufficiently for equity to recognize. and perfect the conveyance if the donor regarded the transaction as a complete act, and died without revoking the gift: on the ground that this would not be against the donor, but in furtherance of his intent. The executor of the donor was therefore considered in equity as trustee for the donee, and the latter could use the name of the executor in a suit on the security.

All this reasoning applies to many other securities, or evidences of undertaking. Hence, the principle has been applied to uphold gifts of a third persons note ${ }^{1}$ although payable to order and unendorsed ${ }^{2}$; to gifts by delivery of a bill of exchange of a third person payable to donor's order, although unendorsed, ${ }^{3}$ or by delivery of certificate of deposit likewise payable to order and unendorsed. ${ }^{4}$

${ }^{1}$ Borneman $v$. Seidlinger, $x_{5}$ Maine, 429 ; Turpin $v$. Thompson, 3 Met. (Ky.) 420 ; Sessions v. Mosley, 4 Cush. (Mass.) 87 ; Bates $v$. Eempton, 7 Gray (Mass.), 382 ; Kilby $v$. Godwin, 2 Del. Ch. 6r ; Holley $v$. Adams, I6 Vt. 206.

${ }^{2}$ Veal v. Veal, 27 Beavan, 303; Brown ข. Brown, I8 Conn. 410; Westerlo v. De Witt, 36 N. Y. 340 ; Daniel v. Smith, 64 Cal. 346. In Brown $v$. Brown, delivery of note secured by mortgage was held to pass the mortgage. See also Jones on Mortgages, par. 817.

${ }^{3}$ Rankin $v$. Weguelin, 27 Beav. 309.

4 Conner v. Root, (Cal.) I7 Pac. Rep. 773 ; Basket v. Hassel, ro7 U. S. 602 ; Gourley v. Linsenbigler, $5 \mathrm{I}$ Pa. 349; Ames v. Witt, 33 Beav. 6I9; In re Taylor, 56 L. I. Rep. (U. S.) 597 ; Westerlo v. De Witt, 36 N. Y. 340; O'Brien v. O'Brien, 5 Ont. 450; Stephenson v. King, a Bush. (Ky.) 228; Moore $v$. Moore, 18 Eq. 474. 
In New York, following the theory of these and other decisions, gifts of certificates of stock have been sustained in equity, although the transfers had not been transferred on the corporation books ${ }^{1}$ and hence not good against the company.

The principle has been applied in cases of gifts of savingsbanks. The ordinary savings-bank book does not represent the debt due by the bank. Suit cannot be brought on the book as it can on a mortgage, a bond, a note. The action is. on the debt, whereof the book is not a representation. It is. not itself a promise by the bank to pay. It is, however, emphatically a part of "the means of getting at the possession" of the money deposited, for the usual rule of savings banks is that the money will not be paid except on presentation of the book. Here it is that Lord Hardwicke's rule and Lord Eldon's in Snelgrove v. Bailey and Duffield v. Elwes, finds its operation. Being the means of getting at the possession, delivery of the book by the depositor will support a gift mortis causa. Such a delivery is a striking evidence of a surrender and delivery of dominion. This has been held in

${ }^{1}$ Walsh v. Sexton, 55 Barb. 25I ; approved in I. Parson's Contracts, 237. See St. Louis Perpetual Ins. Co. v. Goodfellow, 9 Mo. I50; Brown v. Smith, I22 Mass. 589 ; Fitchburg Sag. Bk. v. Torrey, I34 Mass. 239; Hall v. U. S. Ins. Co., 5 Gill (Md.), 484; Grymes v. Hone, 49 N. Y. I7; Cushman $v$. Thayer Mfg. Co., 76 N. Y. 365 ; Cook $v$. Stock, \& 378; Dos. Passos on Stock Brokers, 623. See I Morawetz on Private Corporations, 8226.

It is true, indeed, that there is some slight indication of a disposition in one or two English cases to treat certificates of stock as merely executory in their nature. See Moore $v$. Moore, I8 Eq. Ca. 474; Lambert $v$. Overton, 13 W. R. 227, is ambiguous. In Maryland, an attempt to make a gift by delivery of the certificates with the endorsement of their owner was held to be of no avail : Pennington v. Gitting's Est., 2 Gill \& J. 208, I83o. But the prevailing rule would seem to be as indicated in the text: See Stone $v$. Hackett, 12 Gray (Mass.), 227. The reasoning of Duffin $v$. Duffin, $44 \mathrm{Ch}$. D. ( 1890 ) 76 , is both very strong and very apropos; in that case, a deposit note was held by the Court of Appeals to be the valid subject of a donatio mortis causa. The note bore considerable analogy to savings-bank books; it had on its back a form of check to be signed on withdrawal. Cotton, L. J., said : "If the document was lost, they would require some explanation why it was not forthcoming before they paid the money, but I do not think that they could refuse to pay." The gift. was sustained. 
so many cases that the mere citation of the authorities is somewhat of a task. They are given in the note. ${ }^{1}$

Pennsylvania, ${ }^{2}$ and possibly Maryland, ${ }^{3}$ have decided otherwise. In Great Britain the question remains open." There is considerable reason to believe that the Pennsylvania court will yet apply the same rule to gifts of savings-bank books as it has applied to securities, and uphold the donations. ${ }^{5}$

The principle of Snilgrove v. Bailey and Duffield v. Elwes, that delivery of "the way of coming at the possession" is

1 Massachusetts : Pierce $v$. Savings Bank, 129 Mass. 425. See also Sheedy $v$. Roach, I24 Mass. 472 ; Rockwood v. Wiggins, 16 Gray (Mass.), 402 ; Debinson v. Emmons (Mass.), 33 N. E. Rep. 706.

New York : Ridden $v$. Thrall, 26 N. E. Rep. 627; Walsh v. Bowery Savings Bank, 26 N. E. Rep. 627. See Fiero v. Fiero, 2 Hun. 600, where the case turned on evidence. And see Orr $v$. McGregor, 43 Hun. 531 .

Connecticut: Brown v. Brown, I8 Conn. 410; Camp's Appeal, $3^{6}$ Conn. 88.

Rhode Island : Tillinghast $v$. Wheaton, 8 R. I. 536. And seeProvidence Institution for Savings $v$. Taft, I4 R. I. 502.

Maine: Curtis v. Portland Savings Bank, 77 Maine, I5r ; S. C., 52 Am. Rep. 750. See also Hill $v$. Stevenson, 63 Maine, 364 , a case of gift inter vivos.

Alabama : Jones v. Weakley, 12 S. E. Rep. 420, a dictum.

Kentucky: In this State it has been declared that, so far as the early cases of Ashbrook $v$. Ryan, $2 \mathrm{Bush}, 228$, is opposed to the validity of a gift by delivery of the savings-bank book, it is to be regarded as overruled : Stephenson $v$. King, 8I Ky. 425.

See also the reasoning of the United States Supreme Court in the elaborate opinion in Basket $v$. Hassell, 107 U. S. 602. See also Morse on Banks and Banking, $3 \mathrm{~d}$ Ed., by Prof. Parsons, par. 608; Foss $v$. Lowell Five Cents Savings Bank, II Mass. 285 ; Camp's Appeal, 30 Conn. 88; Brown v. Brown, I8 Conn. 4ro; Davis $\nabla$ Ney, 125 Mass. 590.

In Vermont the question was left undecided in a case in $1867:$ French v. Raymond, $39 \mathrm{Vt} .623$.

2 Walsh's Appeal, 122 Pa. I77.

${ }^{3}$ Murray $v$. Cannon, $4 \mathrm{I}$ Md. 466 . It is of some significance that, in Consar $v$. Snowden, $54 \mathrm{Md}$. I75, the court's remarks were directed rather to the donee's omission to observe certain requirements of the donor. Had the court been opposed to such gifts, these remarks would have been needless.

"See McGonnell v. Murray, Irish Rep. 3 Eq. 450 (1869). In In re Beak, I. R. 13 Eq. 489 , the decision is rested on the fact that the savings-bank book did not embody the terms of the contract. See Dufin $v$. Duffin, note, supra.

${ }^{5}$ See Commonwealth v. Crompton, I37 Pa. I38, at p. I47. 
delivery of dominion and will uphold the gift, has been applied in cases of delivery of the following other instruments : a third person's check, attorney's receipt for obligation filed in a suit, ${ }^{2}$ policy of insurance, ${ }^{3}$ or bill of sale of the policy. ${ }^{4}$

The review that has just been given of the development and extent of the doctrine of equitable gifts mortis causa shows that the House of Lords has been followed fully in its decision in Duffield v. Elwes, ${ }^{5}$ to the effect that "the principle of not assisting a volunteer to perfect an incomplete gift does not apply to a donatio mortis causa," ${ }^{6}$ and in the principle likewise recognized by them that, where the means of getting at possession is delivered, equity will regard the gift as complete.

In the concluding part of this article, we will take up the question whether the donor's own check can be the subject of a gift mortis causa.

(To be concluded.)

Luther E. Hewitt.

Philadelphia, April 15, 1897 .

${ }^{1}$ Burke v. Bishop, 27 La. An. 465.

${ }^{2}$ Elam $v$. Keen, 4 Lehigh (Va.), 333, cited in Yancey $v$. Fields (Va.), 8 S. E. Rep. 721.

${ }^{3}$ Ames $v$. Witt, 33 Beav. 619 ; R. Hughes, 36 W. R. 821.

'Williams v. Guile, II7 N. Y. 343.

${ }^{5}$ I. Bli. N. R. 497.

${ }^{\circ}$ Quoting Lindley, L. J., in Duffin $v$. Duffin, 44 Ch. D. 76, 83 (I89o). 